Разработка способа измерения

массовой концентрации цианидов в почве

с использованием газовой хроматографии и

тандемного масс-селективного детектирования

\author{
Д.О. Корнеев, М.А. Понсов, А.А. Родионов, Л.В. Петракова, И.В. Рыбальченко \\ Федеральное государственное бюджетное учреждение \\ "27 Научный центр» Министерства обороны Российской Федерации, \\ 105005, Российская Федерация, г. Москва, Бригадирский переулок, д. 13
}

\begin{abstract}
Поступила 02.02.2020 г. Принята к публикации 23.02.2020 г.
Конвенцией о запрещении разработки, производства, накопления и применения химического оружия и о его уничтожении под международный контроль в области нераспространения химического оружия поставлены $\mathrm{CN}$-содержащие токсичные химикаты, такие как табун и его многочисленные гомологи и аналоги, насчитывающие во всех вариациях углеродных радикалов около 10 тыс. органических соединений; синильная кислота; хлорциан и другие. Кроме того, $\mathrm{CN}$-содержащие токсичные химикаты представляют собой опасные технологические и экологические загрязнители. Наиболее распространенными и сложными объектами окружающей среды при анализе цианидов являются почвы. Цель работы - разработать способ измерения массовой концентрации цианидов в почве, имеющий преимущество по чувствительности и трудоемкости осуществления в сравнении с приятым в Российской Федерации фотометрическим способом. Разработанный способ предполагает использование в качестве дериватизирующего агента 2,3,4,5,6-пентафторбензилбромид и газовую хроматографию с применением тандемного масс-селективного детектирования в условиях отрицательной химической ионизации метаном. Он позволяет осуществлять идентификацию и количественное определение цианид-ионов в почве в диапазоне 0,7 нг/г-10,0 мкг/г, что более чем на три десятичных порядка превосходит по чувствительности включенный в федеральный реестр фотометрический метод того же назначения. Способ для своего осуществления не требует применения в качестве внутреннего стандарта изотопов цианистого калия с радиоактивными метками углерода и калия, и менее продолжителен по времени.
\end{abstract}

Ключевые слова: 2,3,4,5,6-пентафторбензилбромид; газовая хроматограбия; дериватизаици; идентификация; количественный анализ; проба почвы; хромато-масс-спектрометрия; ицианиды.

Библиографическое описание: Корнеев Д.О., Понсов М.А., Родионов А.А., Петракова Л.В., Рььбальченко И.В. Разработка способа измерения массовой концентрации иичанидов в почвес использованием газовой хроматографии и тандемного масс-селективного детектирования // Вестник войск РХБ защитыь. 2020. T. 4. № 1. C. 4-20. https://doi.org/10.35825/2587-5728-20204-1-4-20

Под международный контроль в области нераспространения химического оружия в списки токсичных химикатов и их прекурсоров «Конвенцией о запрещении разработки, производства, накопления и применения химического оружия и о его уничтожении» (далее - Конвенция) включены $\mathrm{CN}$-содержащие токсичные химикаты $(\mathrm{TX})^{1}$. Среди них в Списке 1 Приложения по

1 Convention on the Prohibition of the Development, Production, Stockpiling and Use of Chemical Weapons and on their Destruction. Organisation for the Prohibition of Chemical Weapons (OPCW), The Hague, The Netherlands, 1997. 179 p. 
химикатам - табун (GA) и его многочисленные гомологи и аналоги, насчитывающие во всех вариациях углеродных радикалов около 10 тыс. органических соединений, а также ТХ Списка 3 синильная кислота и хлорциан [1]. Помимо этого, сам цианид-анион, образующийся в результате гидролиза цианидов, и который имеет прямое отношение ко всем органическим нитрилам и многим неорганическим соединениям (соли синильной кислоты), также подлежит контролю согласно Конвенции [2]. Для них должны существовать надежные способы идентификации и обнаружения в окружающей среде.

Кроме того, цианиды ${ }^{2}$ - опасные экологические и техногенные загрязнители [3-5]. В Российской Федерации содержание цианидов в почве регламентируется гигиеническими нормативами ${ }^{3}$, при этом относительная допустимая концентрация (ОДК) свободных цианидов составляет 1,0 мг/кг почвы, комплексных - 5,0 мг/кг почвы соответственно. Согласно ГОСТ 12.1.007$76^{4}$ и ГОСТ 12.1.005-88 , по степени опасности воздействия на организм синильная кислота и цианиды относятся к I классу опасности веществ. Порядок количественного анализа проб почв на содержание цианидов в Российской Федерации определяется документом ФР.1.31.2017.27246 6 . Указанный документ устанавливает методику измерений содержания цианидов (в том числе, находящихся в форме комплексных соединений) в пробах почв, грунтов, донных отложений, илов, осадков сточных вод, жидких и твердых отходов производства и потребления фотометрическим методом с пиридином и барбитуровой кислотой. Диапазон измерений массовой доли цианидов в почве по данному способу составляет 0,5-130 мг/ кг почвы. В связи с высокой лабильностью свободных цианид-ионов в экологических пробах результат определения напрямую зависит от правильности выполнения условий отбора, транспортировки проб, влажности почвы, сроков проведения анализа после отбора проб, а также чистоты используемых реактивов, особенно барбитуровой кислоты (требования по чистоте - не менее $99 \%)$.

Поэтому в зарубежной аналитической практике качественное и количественное определение цианидов в почве рекомендуется осуществлять с помощью газовой хроматографии с использованием при пробоподготовке способов связывания циан-анионов в хроматографируемые органические нитрилы или тиоцианаты путем дериватизации с помощью 2 (N,N-диалкиламино) этантиолов, замещенных производных диазометана или 2,3,4,5,6-пентафторбензилбромида (CAS 1765-40-8). Аналитический способ определения 2,3,4,5,6-пентафторбензилацетонитрила основан на применении газовой хроматографии в совокупности с масс-селективным детектированием в режимах электронного удара или химической ионизации, а описанный способ пробоподготовки не требует значительных трудозатрат, времени и использования значительного количества лабораторной посуды, дорогостоящих реактивов и растворителей. Предел обнаружения цианиданионов в 1 г почвы, по данным авторов, составляет 1,0 нг. Однако, на наш взгляд, использование в приведенном методе в качестве стандарта труднодоступного цианистого калия с мечеными изотопами атомов углерода и калия представляется излишним [6].

Цель работь - разработать способ измерения массовой концентрации цианидов в почве с использованием газовой хроматографии и тандемного масс-селективного детектирования.

Исходя из анализа литературных источников, наименее трудоемким и оптимальным способом количественного определения циананионов в почве является обработка ее 2,3,4,5,6-пентафторбензилбромидом, при этом в результате алкилирования анионов в интервале температур $50-70{ }^{\circ} \mathrm{C}$ образуется регистрируемый аналит 2,3,4,5,6-пентафторбензилацетонитрил (CAS 653-30-5) (рисунок 1).

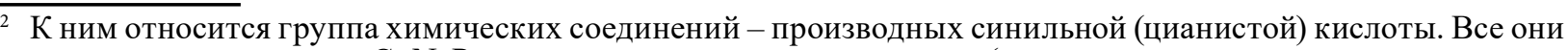
содержат циано-группу - C $\equiv \mathrm{N}$. Различают неорганические цианиды (синильная кислота, цианиды металлов, дициан, галогенцианиды, комплексоны металлов и т.д.) и органические цианиды (например, эфиры или амиды цианмуравьиной и циануксусной кислот, нитрилы, гетерогликозиды и др.).

3 ГН 2.1.7.12-1-2006. Перечень предельно допустимых концентраций (ПДК) и ориентировочно допустимых концентраций (ОДК) химических веществ в почве.

4 Межгосударственный стандарт ГОСТ 12.1.007-76: Система стандартов безопасности труда. Вредные вещества. Классификация и общие требования безопасности.

5 Государственный стандарт ГОСТ 12.1.005-88. Система стандартов безопасности труда. Общие санитарно-гигиенические требования к воздуху рабочей зоны.

6 ФР.1.31.2017.27246 (М4-2017). Количественный химический анализ отходов, почв, грунтов и донных отложений. Методика измерений массовой доли цианидов (в т. ч. находящихся в форме комплексных соединений) в пробах почв, грунтов, донных отложений, илов, осадков сточных вод, жидких и твердых отходов производства и потребления фотометрическим методом с пиридином и барбитуровой кислотой. «Уральский научно-исследовательский институт метрологии» (ФГУП «УНИИМ»). Свидетельство об аттестации № 222.0091/RA.RU.311866/2017 от 21.04.2017. Филиал «ЦЛАТИ по Енисейскому региону ФГБУ «ЦЛАТИ по
} СФО». Красноярск, 2017. 


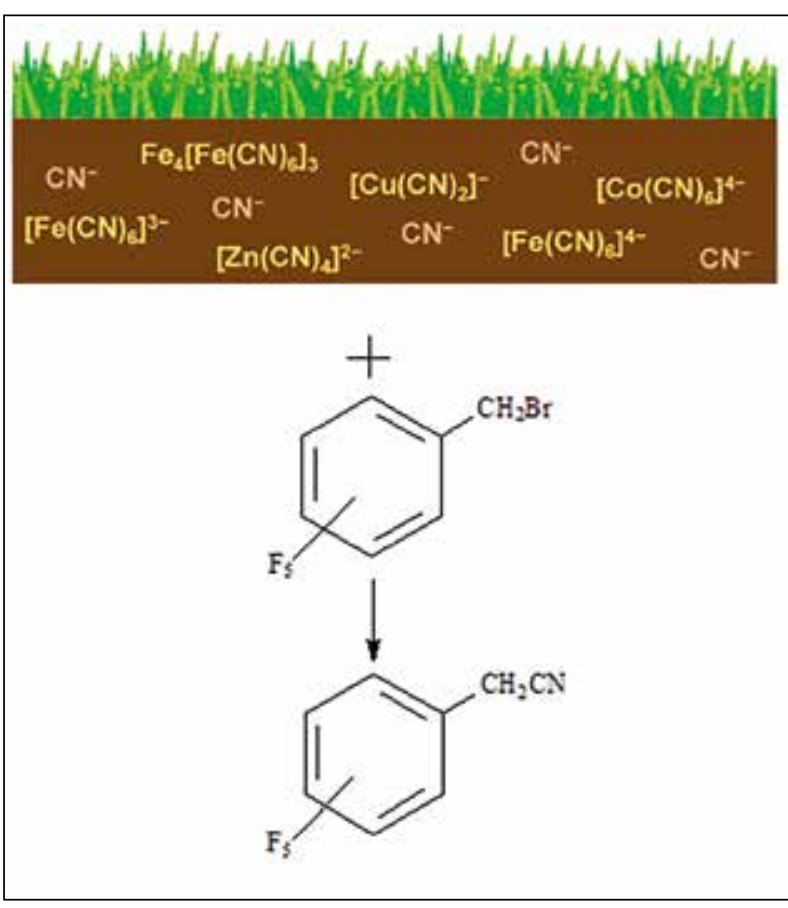

\section{Рисунок 1 - Основная химическая реакция, определяющая способ анализа цианидов на основе связывания цианид-анионов в почве с 2,3,4,5,6-пентафторбензилбромидом [6]}

Для разработки данного способа оценивали основные физико-химические свойства 2,3,4,5,6-пентафторбензилацетонитрила, образующегося в результате дериватизации целевого соединения (таблица 1).

Проведенная оценка указанных в таблице 1 основных физико-химических характеристик целевого аналита позволила в дальнейшем выбрать оптимальные условия пробоподготовки, хроматографирования и детектирования при определении данного вещества в образцах почвы. В качестве стандарта в исследованиях использовали коммерческий образец 2,3,4,5,6-пентафторбензилацетонитрила со степенью чистоты не менее 98,5 \% (фирма «Alfa Aesar», США).

Выбор условий проведения экстракции цианидов из почвы. При проведении процедуры экстракции цианидов из почвы руководствовались рекомендациями, установленными ОЗХО для ежегодных международных профессиональных тестов ${ }^{7}$.

Отбор проб почвы производится в соответствии с требованиями ГОСТ 17.4.3.01-83 ${ }^{8}$, ГОСТ 17.4.4.02-84, и ПНДФ 12.4.2.1-99 ${ }^{11}$ или другими нормативными документами, утвержденными и применяемыми в установленном порядке.

Пробы отбирают в емкости (банки) из темного стекла с притертой или плотно завинчивающейся крышкой, заполняя емкости «под горло». Масса отобранной пробы должна составлять не менее 100 г. При отборе полужидких образцов почв, пастообразных проб или проб, имеющих значение $\mathrm{pH}<5$ (по универсальной индикаторной бумаге), рекомендуется использовать для отбора колбы со шлифом. Колбу закрывают притертой пробкой и привинчивают ее к колбе тонкой проволокой.

Емкости с отобранными в них пробами доставляют в лабораторию и хранят в закрытом виде не более 10 сут при температуре не выше $10{ }^{\circ} \mathrm{C}$. Доставленную в лабораторию пробу перед анализом усредняют. Для этого весь объем пробы извлекают из емкости, удаляют механические примеси (камешки, корни и пр.) и тщательно перемешивают растиранием пестиком в фарфоровой ступке соответствующего объема.

После усреднения часть пробы используют для анализа, оставшуюся часть помещают в чистую емкость и хранят при условиях и сроках, описанных выше; при необходимости ее используют для получения повторных результатов и проведения внутрилабораторного контроля. После отбора проб составляется акт (протокол) отбора пробы по установленной в лаборатории форме, в котором указываются: наименование и адрес обследуемого предприятия; цель анализа, предполагаемые загрязнители; наименование анализируемого объекта (отходы, почва и т.д.), место, дата и время отбора; тип пробы (точечная, составная); номер пробы; условия

\footnotetext{
Recommended Operating Procedures for Analysis in the Verification of Chemical Disarmament: 2017 Edition. Editor: Paula Vanninen. The Ministry for Foreign Affairs of Finland University of Helsinki. VERIFIN, Department of Chemistry P.O. Box 55, fin-00014 - University of Helsinki, Finland., 286 p., ISBN 978-952-10-7408-0.

OPCW Technical Secretariat. Quality management system document № QDOC/LAB/SOP/PT01-PT04, Standard Operating Procedure for the organisation of OPCW proficiency tests: Philippe Denier, Director of the Verification Division. Issue № 3, Revision № 5, April 2019.

8 ГОСТ 17.4.3.01-83. Почвы. Общие требования к отбору проб.

9 ГОСТ 17.4.4.02-84. Почвы. Методы отбора и подготовки проб для химического, бактериологического, гельминтологического анализа.

10 ПНДФ 12.1:2:2.2:2.3:3.2-2003. Отбор проб почв, грунтов, осадков биологических очистных сооружений, шламов промышленных сточных вод, донных отложений искусственно созданных водоемов, прудов-накопителей и гидротехнических сооружений.

11 ПНДФ 12.4.2.1-99. Отходы минерального происхождения. Рекомендации по отбору и подготовке проб. Общие положения.
} 
Таблица 1 - Основные физико-химические свойства 2,3,4,5,6-пентафторбензилацетонитрила [7]

\begin{tabular}{|c|c|}
\hline $\begin{array}{c}\text { Свойство, } \\
\text { единица измерения }\end{array}$ & Значение или показатель \\
\hline Структурная формула & \\
\hline Номер по номенклатуре CAS & $653-30-5$ \\
\hline $\begin{array}{c}\text { Название по номенклатуре IUPAC (синонимы и } \\
\text { международные торговые названия) }\end{array}$ & $\begin{array}{c}\text { 2,3,4,5,6-Pentafluorophenylacetonitrile } \\
\text { (2,3,4,5,6-pentafluorobenzyl cyanide, benzeneacetonitrile, } \\
\text { 2,3,4,5,6-pentafluoro-, pentafluorophenylacetonitrile, } \\
\text { pentafluorobenzeneacetonitrile) }\end{array}$ \\
\hline Брутто-формула & $\mathrm{C}_{8} \mathrm{H}_{2} \mathrm{~F}_{5} \mathrm{~N}$ \\
\hline Молекулярная масса, а.е.м. & 207,102 \\
\hline Атомарный состав & $\mathrm{C}(46,40 \%), \mathrm{H}(0,97 \%), \mathrm{F}(45,87 \%), \mathrm{N}(6,76 \%)$ \\
\hline Агрегатное состояние & Бесцветная жидкость \\
\hline Плотность при $20^{\circ} \mathrm{C}$, г/см & 1,515 \\
\hline Температура кипения при н.у., ${ }^{\circ} \mathrm{C}$ & $223\left(107-111^{\circ} \mathrm{C} / 17\right.$ мм рт.ст.) \\
\hline Температура плавления, ${ }^{\circ} \mathrm{C}$ & минус 56-58 \\
\hline Показатель преломления, nD²0 & 1,439 \\
\hline Температура вспышки, ${ }^{\circ} \mathrm{C}$ & $72-73$ \\
\hline $\begin{array}{c}\text { Давление насыщенного пара, } \\
\text { мм рт.ст. при } t=25^{\circ} \mathrm{C} \\
\end{array}$ & $0,1-0,4$ \\
\hline $\begin{array}{c}\text { Коэффициент произведения растворимости, } \\
\text { LogP, усл. ед. }\end{array}$ & $1,63 \pm 0,4$ \\
\hline Фактор биоконцентрирования, BCF, усл. ед. & 10,26 \\
\hline Растворимость & В воде - плохо, в органических растворителях - хорошо \\
\hline
\end{tabular}

отбора проб; должности, фамилии лиц, участвующих в отборе, подписи, дата.

Далее определяют влажность почвы. Для пересчета массы навески на абсолютно сухую пробу определяют содержание гигроскопической влаги. Для этого берут 3 навески пробы по 0,2 г, помещают в предварительно подготовленные фарфоровые чашки и высушивают при $t=(105 \pm 5)^{\circ} \mathrm{C}$ в сушильном шкафу до постоянной массы. Жидкие пробы предварительно выпаривают на водяной бане досуха.

$\mathrm{g}=\left(\mathrm{P}-\mathrm{P}_{\text {cyx }}\right) \times 100 / \mathrm{P}$

где g - содержание гигроскопической влаги, \%;

P - масса пробы, взятой для полного высушивания, г;

$\mathrm{P}_{\text {сух }}$ - масса полностью высушенной пробы, г.

При выполнении условия: $\left|\mathrm{g}_{\max }-\mathrm{g}_{\min }\right|<12 \%$ вычисляют $\mathrm{g}_{\text {ср. }}(\%)$ :

$$
\mathrm{g}_{\text {cp. }}=\left(\mathrm{g}_{1}+\mathrm{g}_{2}+\mathrm{g}_{3}\right) / 3 \quad(2)
$$

Далее определяют коэффициент пересчета на абсолютно сухую пробу:

$$
\mathrm{K}=\left(100-\mathrm{g}_{\text {ср. }}\right) / 100 \text {, }
$$

где $\mathrm{g}_{\text {ср. }}$ - содержание гигроскопической влаги, \%.

Точная масса (кг) навески абсолютно сухой пробы, взятой для анализа, рассчитывается по формуле:

$\mathrm{m}_{\text {aбc.cyx. }}=\mathrm{m} \times \mathrm{K} / 1000$,

где m - масса пробы, взятая для анализа, г.

К - коэффициент пересчета (см. выше формулу 3).

Подготовка стандартных растворов (два способа) и построение градуировочнойзависимости

1. Готовят не менее 10 растворов стандартного образца $(2,3,4,5,6$-пентафторбензилацетонитрила) в абсолютном этилацетате, с различными концентрациями в диапазоне 10 нг/мл - 10 мкг/мл. Вносят в 10 виал с завинчивающейся крышкой, содержащих по 1,0 г предварительно подготовленной навески почвы, заданное количество раствора стандартного образца. Виалы герметично закрывают, встряхивают на шейкере в течение 2 часов. Добавляют в каждую виалу по 1,0 мл этилацетата, встряхивают на шейкере, 
центрифугируют при 15000 об/мин и отбирают центрифугат. Полученные растворы упаривают до остаточного объема 500 мкл в токе азота при комнатной температуре. Эксперимент повторяют 5-6 раз. Далее все образцы подвергают ГХ-анализу для построения градуировочной зависимости.

2. Готовят исходный раствор стандарта цианистого калия (CAS 151-50-8) с содержанием основного вещества не менее 99,8 \% в абс. этилацетате с концентрацией 1,0 мкг/мл. После этого вносят в 10 виал, содержащих по 1,0 г предварительно подготовленной навески почвы расчетное количество раствора цианистого калия с заданными концентрациями в диапазоне 10 нг/мл 10 мкг/мл. Виалы герметично закрывают, встряхивают на механическом шейкере в течение 2 часов. Помещают все виалы в термостат и в каждую добавляют расчетное количество 2,3,4,5,6-пентафторбензилбромида. Встряхивают виалы при $t=50{ }^{\circ} \mathrm{C}$ в течение 2 часов. После охлаждения центрифугируют при 15 тыс. об/мин и отбирают центрифугат. Полученные растворы упаривают до остаточного объема 500 мкл в токе азота при комнатной температуре. Эксперимент повторяют 5-6 раз. Далее все образцы подвергают ГХ-анализу для построения градуировочной зависимости.

Экстракция ичианид-ионов из проб почвы

Образец анализируемой почвы массой 1,0 г помещают в виалу с завинчивающейся крышкой, приливают 2 мл абс. этилацетата. Встряхивают виалу на механическом шейкере в течение 0,5 часа, добавляют 100 мкл 2,3,4,5,6-пентафторбензилбромида. Встряхивают виалу при $t=50^{\circ} \mathrm{C}$ в течение 2 часов. Охлаждают виалу, центрифугируют при 15 тыс. об/мин и отбирают центрифугат. Полученный раствор упаривают до остаточного объема 500 мкл в токе азота при комнатной температуре. Эксперимент повторяют 5-6 раз. Далее образец подвергают ГХ-анализу для определения содержания цианид-ионов в пробе почвы с использованием ранее построенной градуировочной зависимости.

Разработка хромато-масс-спектрометрического способа определения концентрации цианид-ионов в пробах почвы. Построение калибровочной зависимости, а также количественное определение содержания цианиданионов в анализируемой почве проводилось с использованием хромато-масс-аналитической станции, включающей газовый хроматограф
«Agilent 7890A» и трехквадрупольный масс-селективный детектор типа «Agilent 7000B GC/ MS Triple Quad» фирмы «Agilent Technologies, Inc.», США. Для разделения смесей в хроматографе применялась кварцевая капиллярная колонка типа «DB-5MS Ultra Inert» длиной $30 \mathrm{~m}$ с внутренним диаметром 0,25 мм и толщиной неподвижной фазы полисилоксана 0,25 мкм.

Подготовка газового хроматографа, масс-селективного детектора проводилась в соответствии с руководством пользователя ${ }^{12}$. Обработка и расчеты полученных хроматографических и масс-спектральных данных проводились на ПЭВМ «НР Compaq 530» фирмы «Hewlett Packard» (США) с использованием лицензионного программного обеспечения ${ }^{13}$. Для математических расчетов градуировочных зависимостей также использовалось лицензионное программное обеспечение ${ }^{14}$.

В качестве дериватизирующего агента применялся коммерческий 2,3,4,5,6-пентафторбензилбромид (CAS 1765-40-8) со степенью чистоты не менее 99,5\% фирмы «Alfa Aesar», США.

Разработка и поиск оптимальных условий разделения смесей и идентификации включали в себя проведение анализа образцов проб почвы на наличие в них определяемого аналита $(2,3,4,5,6$-пентафторбензилацетонитрила) с использованием трех типов ионизации (таблица 2):

- электронной (70 эВ);

- химической ионизации метаном с регистрацией отрицательных ионов;

- химической ионизации метаном с регистрацией положительных ионов.

Для определения предела обнаружения цианид-ионов в почве в рамках разработанного хромато-масс-спектрометрического способа проводился анализ растворов с различной концентрацией аналита и анализ проб почвы, искусственно зараженных цианидом калия, с такими же значениями концентраций, как у набора стандартных растворов.

Ввод проб и проведение анализа выполнялись в соответствии с параметрами и условиями, указанными в таблице 2. Масс-спектры электронного удара, зарегистрированные при сканировании в режиме «MS1SCAN», совпадали с библиотечными данными. Степень совпадения полученных масс-спектров определяемого аналита с библиотечными данными

\footnotetext{
$\overline{12}$ Руководство пользователя работы с газовым хроматографом «Agilent 7890A» и масс-селективным детектоpom «Agilent 7000B GC/MS Triple Quad»: «Agilent Technologies, Inc.», CШA, 2013.

${ }^{13}$ Mass Hunter Workstation Software, Qualitative and Quantitative Analysis, version B.08.00 build 4.0.548.0: Agilent Technologies, Inc., США. 2016.

${ }^{14}$ Математическая программа расчетов / Mathcad-2018, Add-In for Excel ver. 15.0.02.A7 for Windows 7,8,XP.
} 
Development of a method for measuring mass concentration of cyanides in soil samples using gas chromatography...

\section{Таблица 2 - Оптимальные условия и значения газохроматографического разделения и масс-спектрометрического детектирования для определения \\ 2,3,4,5,6-пентафторбензилацетонитрила в различных режимах и типах ионизации}

\begin{tabular}{|c|c|c|c|}
\hline \multirow{2}{*}{\begin{tabular}{|c|} 
Условия или параметры \\
газохроматографического разделения \\
и масс-спектрометрического \\
детектирования
\end{tabular}} & \multicolumn{3}{|c|}{ Тип ионизации } \\
\hline & Электронная & $\begin{array}{c}\text { Химическая (метаном), } \\
\text { положительная }\end{array}$ & $\begin{array}{c}\text { Химическая (метаном), } \\
\text { отрицательная }\end{array}$ \\
\hline & \multicolumn{3}{|c|}{ Значение параметра } \\
\hline Ввод пробы & \multicolumn{3}{|c|}{ Программируемый, с помощью автосамплера «Agilent 7693А» } \\
\hline Объем вводимого раствора аналита, мкл & \multicolumn{3}{|c|}{1,0} \\
\hline Режим ввода пробы & \multicolumn{3}{|c|}{ Без разделения потока (Splitless), 1 мин } \\
\hline Температура ввода пробы (испаритель), ${ }^{\circ} \mathrm{C}$ & 270 & 280 & 280 \\
\hline Время задержки растворителя, мин & 2 & 5 & 5 \\
\hline Тип ввода пробы & \multicolumn{3}{|c|}{ Вертикальный } \\
\hline $\begin{array}{c}\text { Тип и неподвижная фаза } \\
\text { хроматографической колонки }\end{array}$ & \multicolumn{3}{|c|}{$\begin{array}{l}\text { Agilent DB-5MS Ultra Inert / (5 \% phenyl } 95 \% \text { dimethyl arylene } \\
\text { siloxane, CШA), } 30 \mathrm{~m} \times 0.25 \mathrm{~mm} \times 0.25 \mu \mathrm{m}\end{array}$} \\
\hline $\begin{array}{c}\text { Режим программирования температуры } \\
\text { термостата колонки }\end{array}$ & \multicolumn{3}{|c|}{$40^{\circ} \mathrm{C}(1 \mathrm{~min}), 10^{\circ} \mathrm{C} / \mathrm{min} 280^{\circ} \mathrm{C}(5 \mathrm{~min})$} \\
\hline Газ-носитель & \multicolumn{3}{|c|}{1,439} \\
\hline $\begin{array}{c}\text { Скорость потока гелия через колонку, } \\
\text { мл/мин }\end{array}$ & \multicolumn{3}{|c|}{$72-73$} \\
\hline $\begin{array}{c}\text { Скорость и время потока гелия после } \\
\text { разгонки }\end{array}$ & \multicolumn{3}{|c|}{$0,1-0,4$} \\
\hline Вакуум внешнего насоса, мм рт. ст. & \multicolumn{3}{|c|}{$1,63 \pm 0,4$} \\
\hline $\begin{array}{c}\text { Вакуум внутреннего турбонасоса, } \\
\text { мм рт. ст. }\end{array}$ & \multicolumn{3}{|c|}{10,26} \\
\hline Растворимость & \multicolumn{3}{|c|}{ В воде - плохо, в органических растворителях - хорошо } \\
\hline Газ-носитель & \multicolumn{3}{|c|}{$\begin{array}{c}\text { Гелий сжатый газообразный высокой чистоты марки «7.0», } \\
\text { чистота не менее 99,99999 \% (по ТУ 0271-001-45905715-02) } \\
\text { фирмы ООО «НИИ КМ» (Россия) }\end{array}$} \\
\hline $\begin{array}{c}\text { Скорость потока гелия через колонку, } \\
\text { мл/мин }\end{array}$ & \multicolumn{3}{|c|}{ Постоянная, 1,0 } \\
\hline $\begin{array}{c}\text { Скорость и время потока гелия после } \\
\text { разгонки }\end{array}$ & \multicolumn{3}{|c|}{60 мл/мин в течение 1 мин } \\
\hline Вакуум внешнего насоса, мм рт. ст. & \multicolumn{3}{|c|}{$(2,18-2,48) \times 10^{-1}$} \\
\hline $\begin{array}{l}\text { Вакуум внутреннего турбонасоса, } \\
\text { мм рт. ст. } \\
\end{array}$ & \multicolumn{3}{|c|}{$(6,95-7,56) \times 10^{-5}$} \\
\hline Скорость потока гелия & \multicolumn{3}{|c|}{3,0} \\
\hline $\begin{array}{c}\text { Число промываний иглы шприца } \\
\text { абсолютным хлористым метиленом } \\
\text { (до ввода пробы и после) }\end{array}$ & \multicolumn{3}{|c|}{$5-6$} \\
\hline Тип масс-селективного детектора & \multicolumn{3}{|c|}{ Тройной квадруполь } \\
\hline $\begin{array}{c}\text { Режимы масс-селективного } \\
\text { детектирования }\end{array}$ & \multicolumn{3}{|c|}{ «MS1SCAN», «Product Ion Scan», «MRM» } \\
\hline $\begin{array}{c}\text { Диапазон сканируемых масс в режиме } \\
\text { «MS1SCAN», a.e.м. }\end{array}$ & \multicolumn{3}{|c|}{$25-350$} \\
\hline $\begin{array}{c}\text { Внутренний калибровочный стандарт для } \\
\text { ионизации }\end{array}$ & $\begin{array}{c}\text { Перфтортрибу- } \\
\text { тиламин } \\
\end{array}$ & \multicolumn{2}{|c|}{ Перфтор-5,8-диметил-3,6,9-триоксидодекан } \\
\hline Газ-реагент для химической ионизации & - & \multicolumn{2}{|c|}{$\begin{array}{c}\text { Метан газообразный сжатый 99,9995 \%, } \\
\text { степень чистоты - } 5.5 \text { по ISO/IEC 17050- } \\
\text { 1:2004, производство ФРГ (фирма «Linde AG, } \\
\text { Geschaftsbereich Linde Gas») }\end{array}$} \\
\hline
\end{tabular}




\begin{tabular}{|c|c|c|c|}
\hline \multirow{2}{*}{\begin{tabular}{|c|} 
Условия или параметры \\
газохроматографического разделения \\
и масс-спектрометрического \\
детектирования \\
\end{tabular}} & \multicolumn{3}{|c|}{ Тип ионизации } \\
\hline & Электронная & $\begin{array}{c}\text { Химическая (метаном), } \\
\text { положительная }\end{array}$ & $\begin{array}{c}\text { Химическая (метаном), } \\
\text { отрицательная }\end{array}$ \\
\hline & \multicolumn{3}{|c|}{ Значение параметра } \\
\hline Газ ячейки соударений & \multicolumn{3}{|c|}{$\begin{array}{c}\text { Азот сжатый газообразный высокой чистоты, чистота не менее } \\
\text { 99,9999\% (по ТУ 2114-009-45905715-2011) фирмы ООО «НИИ } \\
\text { КМ» (Россия) }\end{array}$} \\
\hline $\begin{array}{c}\text { Скорость потока гелия в ячейке } \\
\text { соударений, мл/мин }\end{array}$ & \multicolumn{3}{|c|}{2,25} \\
\hline $\begin{array}{c}\text { Скорость потока азота в ячейке } \\
\text { соударений, мл/мин }\end{array}$ & \multicolumn{3}{|c|}{1,5} \\
\hline $\begin{array}{c}\text { Скорость потока метана в источник } \\
\text { ионизации, мл/мин }\end{array}$ & - & 1,0 & 2,0 \\
\hline Температура источника ионов, ${ }^{\circ} \mathrm{C}$ & 230 & 250 & 150 \\
\hline $\begin{array}{c}\text { Основные масс-энергетические переходы } \\
\text { в режиме сканирования MRM, m/z } \\
\text { (продукт ион } \rightarrow \text { прекурсор ион), энергия } \\
\text { ячейки соударений (CE, эB еВ) }\end{array}$ & $\begin{array}{l}m / z 207 \rightarrow \\
157(13 \text { эB) } \\
m / z 207 \rightarrow \\
188(9 \text { эB) }\end{array}$ & - & $\begin{array}{c}m / z 187 \rightarrow \\
167(8 \text { эB), } \\
m / z 187 \rightarrow 98(16 \text { эВ) }\end{array}$ \\
\hline $\begin{array}{c}\text { Наиболее интенсивный определяемый } \\
\text { ион в режиме «Produt Ion Scan», m/z }\end{array}$ & $207[\mathrm{M}]^{+}$ & $208[M+1]^{+}$ & $187[\mathrm{M}-(\mathrm{HF})]^{-}$ \\
\hline Температура переднего квадруполя, ${ }^{\circ} \mathrm{C}$ & \multicolumn{3}{|c|}{150} \\
\hline Температура интерфейса, ${ }^{\circ} \mathrm{C}$ & \multicolumn{3}{|c|}{285} \\
\hline Температура заднего квадруполя, ${ }^{\circ} \mathrm{C}$ & \multicolumn{3}{|c|}{150} \\
\hline Время сканирования, циклов/с & \multicolumn{3}{|c|}{ 5,1-6,8 (35-51 мс/цикл) } \\
\hline Масс-разрешение & \multicolumn{3}{|c|}{ Unit } \\
\hline Ширина щели пучка ионов, условных ед. & \multicolumn{3}{|c|}{150} \\
\hline Шаг сканирования, а.е.м. & \multicolumn{3}{|c|}{0,1} \\
\hline Порог детектирования, усл. ед. & \multicolumn{3}{|c|}{100} \\
\hline Коэффициент усиления сигнала (Gain) & \multicolumn{3}{|c|}{$5-10$} \\
\hline Энергия эмиссии электронов, эВ & 70 & 200 & 145 \\
\hline Сила тока эмиссии электронов, мкА & 35 & 150 & 50 \\
\hline $\begin{array}{c}\text { Время удерживания хроматографического } \\
\text { сигнала, мин }\end{array}$ & $8,67 \pm 0,1$ & $8,69 \pm 0,1$ & $8,67 \pm 0,1$ \\
\hline Ширина детектируемого пика, с & \multicolumn{3}{|c|}{0,7} \\
\hline
\end{tabular}

оказалась в диапазоне 97-98 \%, что свидетельствует о достоверной идентификации ${ }^{15}$.

Хроматограммы по полному ионному току и масс-спектры электронной и химической ионизации определяемого 2,3,4,5,6-пентафторбензилацетонитрила, зарегистрированные при сканировании в режиме «MS1SCAN», приведены на рисунках 2-4.

В масс-спектре электронной ионизации определяемого аналита (рисунок 2) наиболее интенсивный сигнал иона с $\mathrm{m} / \mathrm{z} 207$ соответствует молекулярному иону $[\mathrm{M}]^{+}$. Предполагаемая нами схема фрагментации 2,3,4,5,6-пентафторбензил ацетонитрила при электронной ионизации представлена на рисунке 5.

В масс-спектре положительной химической ионизации (рисунок 3) наиболее интенсивный сигнал иона с $\mathrm{m} / z 208$ соответствует квазимолекулярному иону $[\mathrm{M}+1]^{+}$; наличие сигналов ионов с $m / z 236[\mathrm{M}+29]^{+}$и $\mathrm{m} / z 248[\mathrm{M}+41]^{+}$ соответствует образованию так называемых аддуктивных ионов $\left[\mathrm{M}+\mathrm{C}_{2} \mathrm{H}_{5} \cdot\right]^{+}$и $\left[\mathrm{M}+\mathrm{C}_{3} \mathrm{H}_{5} \cdot\right]^{+}$, что характерно для большинства органических соединений [8].

$\overline{15}$ OCAD-OPCW Central Analytical DATABASE. OPCW Mass Spectral Database (v.21 2019, January 2019. Программа поиска MS NIST для Windows и NIST/EPA/NIH Масс-спектральная База данных в формате NIST и Формате ChemStation. Mass Spectral Database (NIST-17) (№G1033-60049). Национальный институт стандартов и технологии США, Шт. Мэриленд 20899-8320, 100 Bureau Drive Stop 8380. Гейтерсбург. 
Разработка способа измерения массовой концентрации цианидов в почве...

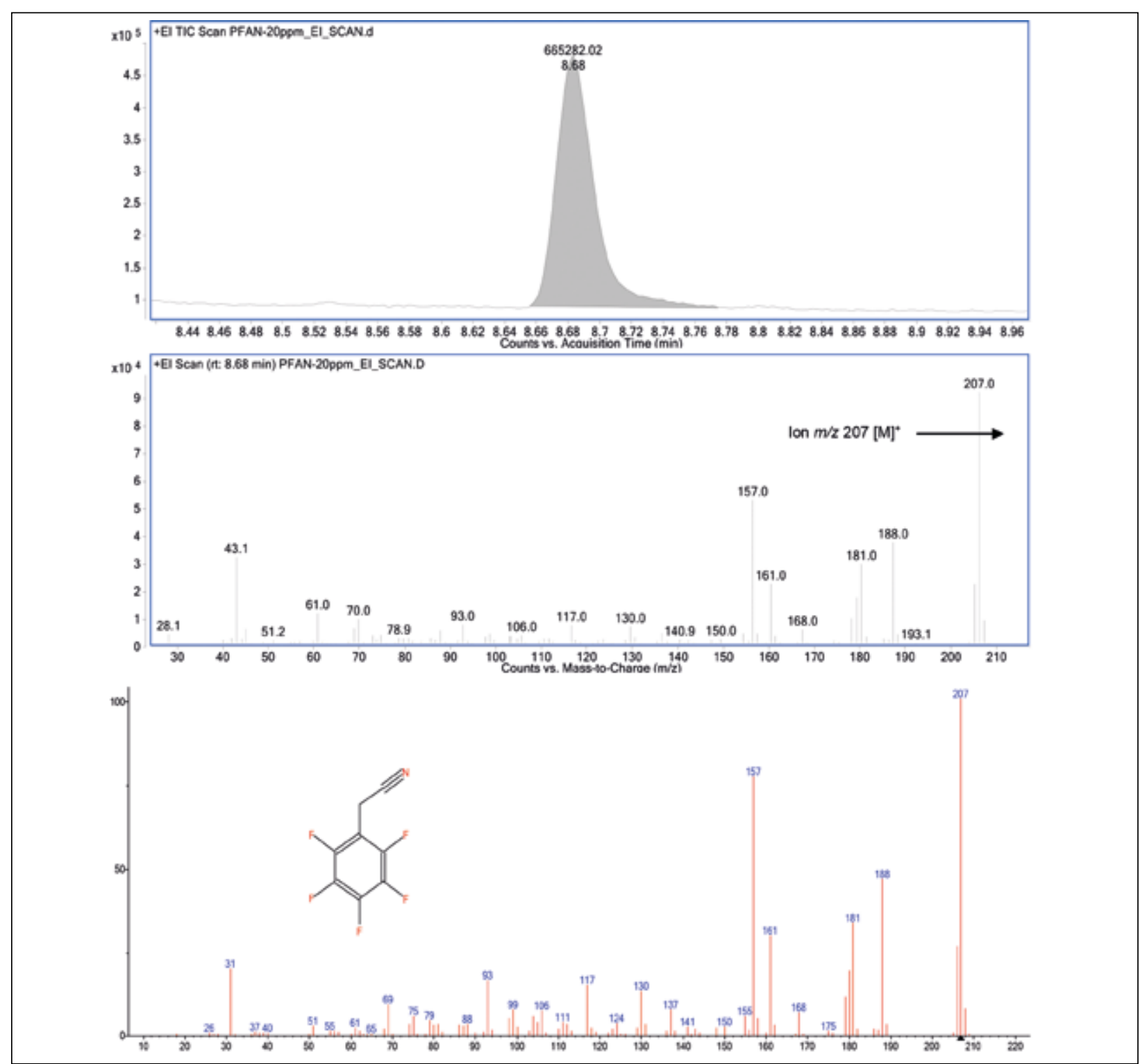

Рисунок 2 - Фрагмент хроматограммы по полному ионному току и масс-спектр электронной ионизации 2,3,4,5,6-пентафторбензилацетонитрила, зарегистрированные при сканировании $в$ режкиме «MS1SCAN» (концентрация аналита - 10 мкг/мл в абс. этилацетате).

Снизу приведен сравнительный масс-спектр электронной ионизации данного вещества из библиотеки масс-спектров NIST (см. сноску 15)

С другой стороны, масс-спектр отрицательной химической ионизации $2,3,4,5,6-$-пентафторбензилацетонитрила (рисунок 4) менее информативен. Так, в данном спектре зарегистрирован только один интенсивный ион с $m / z 187$ [M-19]', что соответствует фрагменту [M-(HF)].

Полученные хроматограммы и MS/MSспектры в режимах электронной и отрицательной химической ионизации приведены на рисунках 6 и 7. Хроматограммы и MS/MSспектры положительной химической ионизации не приводятся в связи с их низкой информативностью.
Выбор параметров и условий MS/ MS-сканирования целевого аналита в наиболее чувствительном режиме - мониторинг множественных реакций «MRM»-базировался на экспериментальном поиске оптимальной энергии ячейки соударений (Collision Energy, CE) для каждого из двух масс-энергетических переходов как при электронной, так и при отрицательной химической ионизации.

Известно, что наибольший отклик МСД при анализе сверхнизких концентраций аналитов (на уровне десятых долей нанограмм) для большинства органических соединений в 
D.O. Korneev, M.A. Ponsov, A.A. Rodionov et al.

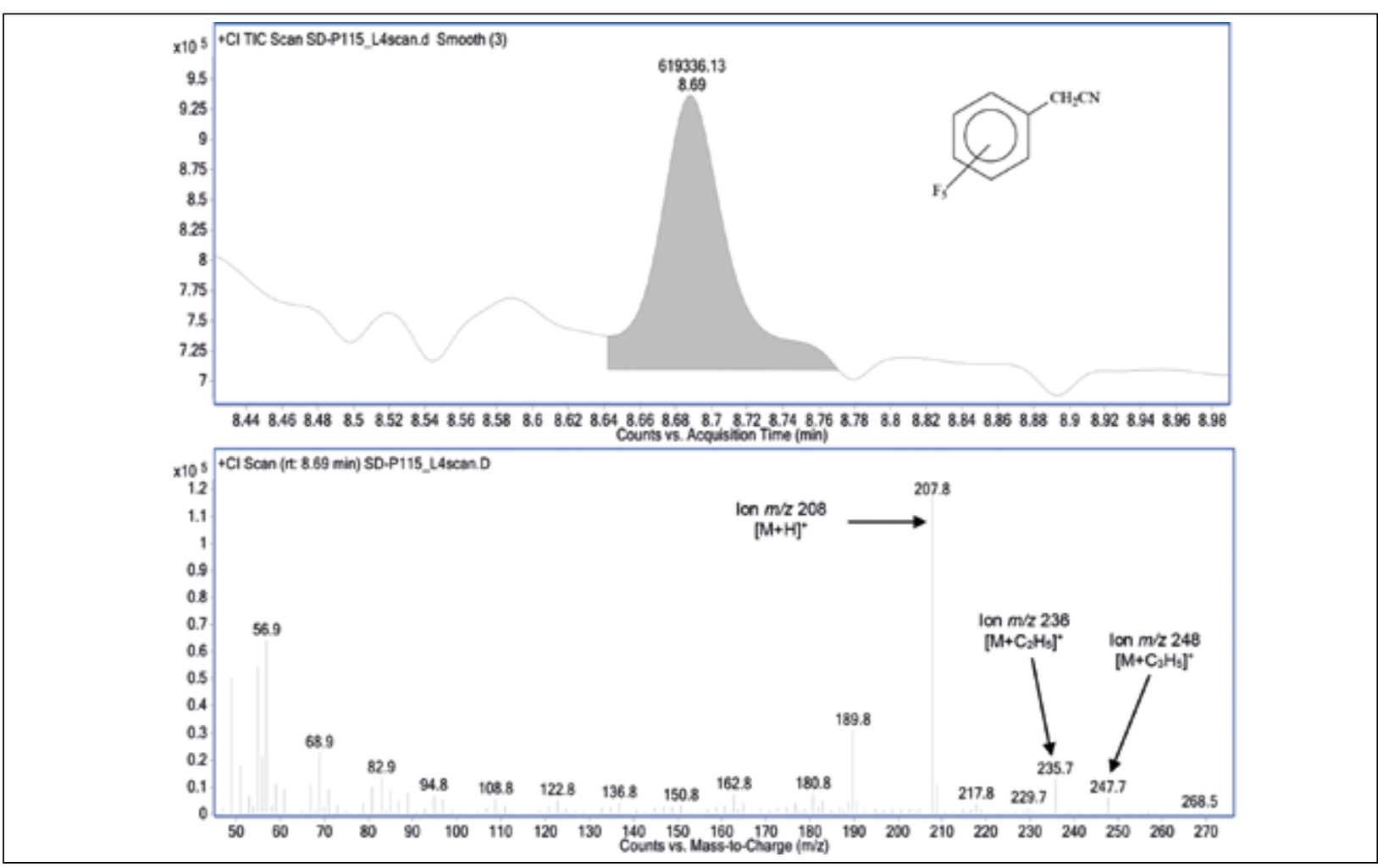

Рисунок 3 - Фрагмент хроматограммы по полному ионному току и масс-спектр положительной химической ионизации 2,3,4,5,6-пентафторбензилацетонитрила, зарегистрированные при сканировании в режкиме "MS1SCAN» (концентрация аналита - 1,0 мкг/мл в абс. этилацетате)

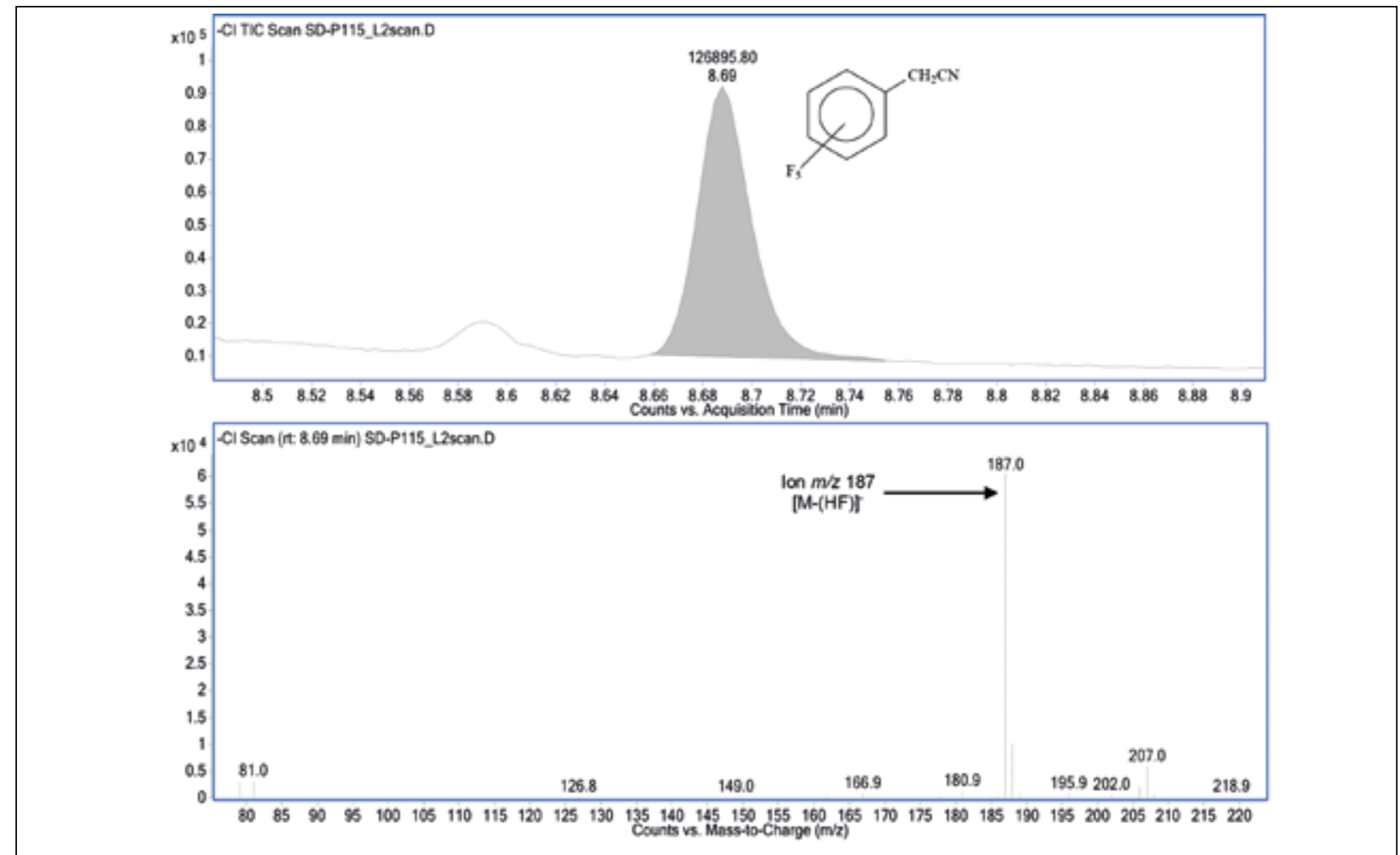

Рисунок 4 - Фрагмент хроматограммы по полному ионному току и масс-спектр отрицательной химической ионизации 2,3,4,5,6-пентафторбензилацетонитрила, зарегистрированные при сканировании в режиме «MS1SCAN» (концентрация аналита - 1,0 мкг/мл в абс. этилацетате) 
Development of a method for measuring mass concentration of cyanides in soil samples using gas chromatography...<smiles>N#Cc1c([18OH])c(F)c(F)c(F)c1F</smiles><smiles>C[C+]CCCCC</smiles><smiles>N#Cc1cccc(F)c1F</smiles><smiles>N#Cc1ccccc1CCc1ccccc1</smiles>
$\mathrm{m} / \mathrm{z} 188[\mathrm{M}-19]^{*}$

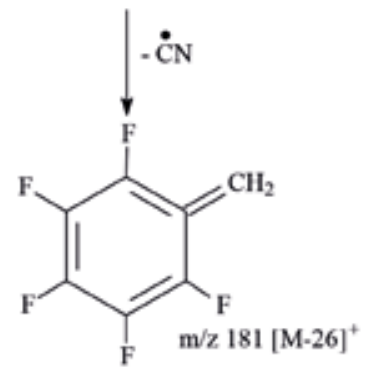

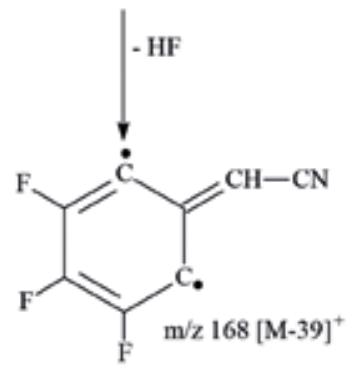

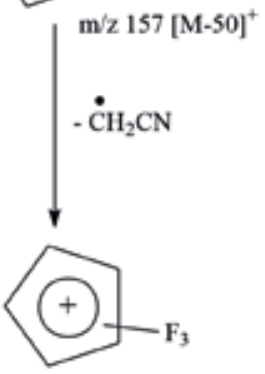

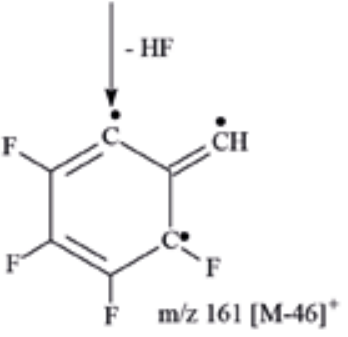

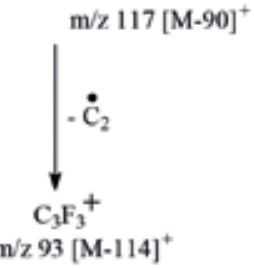

Рисунок 5 - Предполагаемые пути фрагментации 2,3,4,5,6-пентафторбензилацетонитрила при электронной ионизации

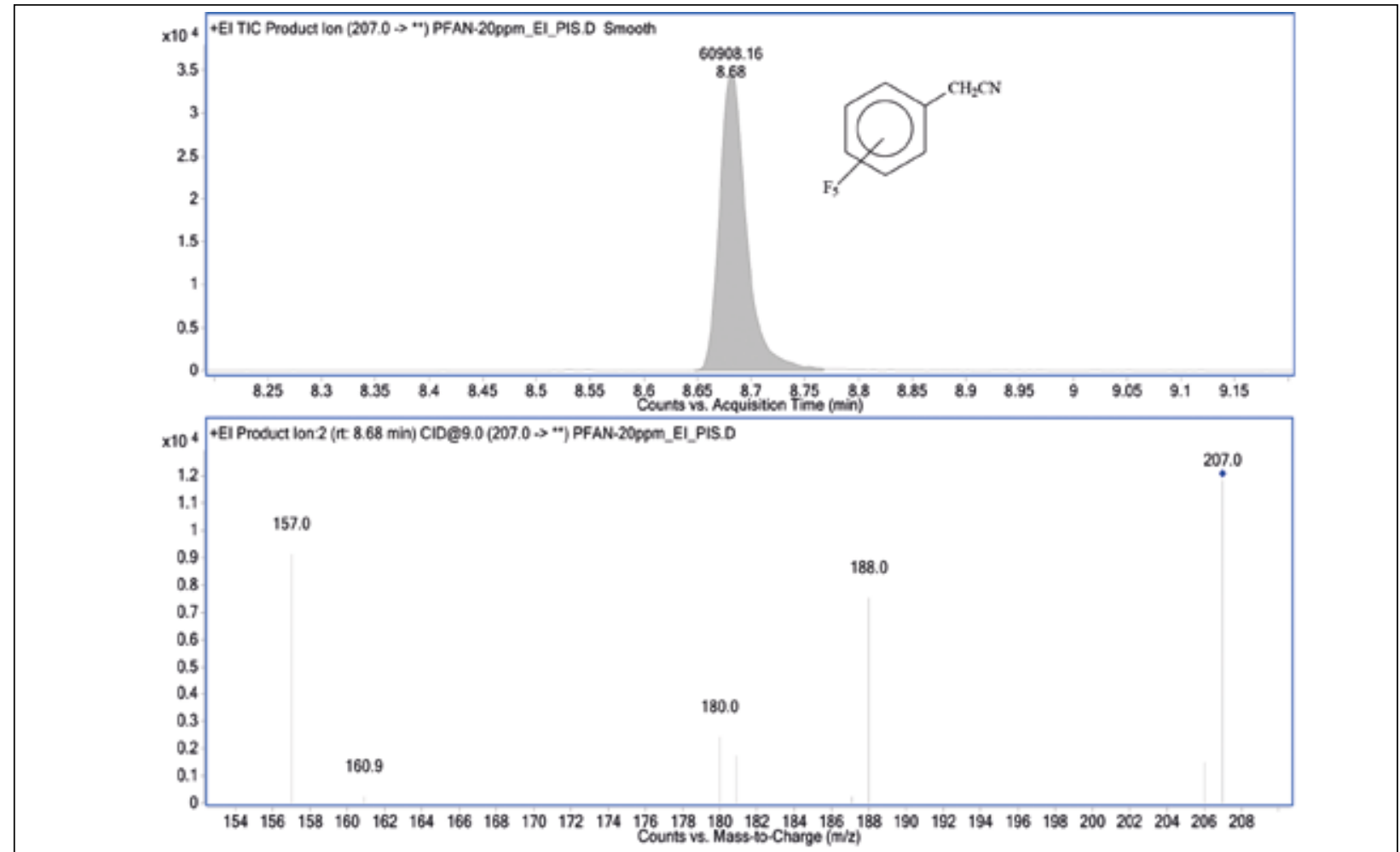

Рисунок 6 - Фрагмент хроматограммы по полному ионному току и MS/MS - спектр электронной ионизации 2,3,4,5,6-пентафторбензилацетонитрила, зарегистрированные при MS/MS - сканировании в режиме "Product lon Scan» (m/z 207) (концентрация аналита - 20,0 мкг/мл в абс. этилацетате) 


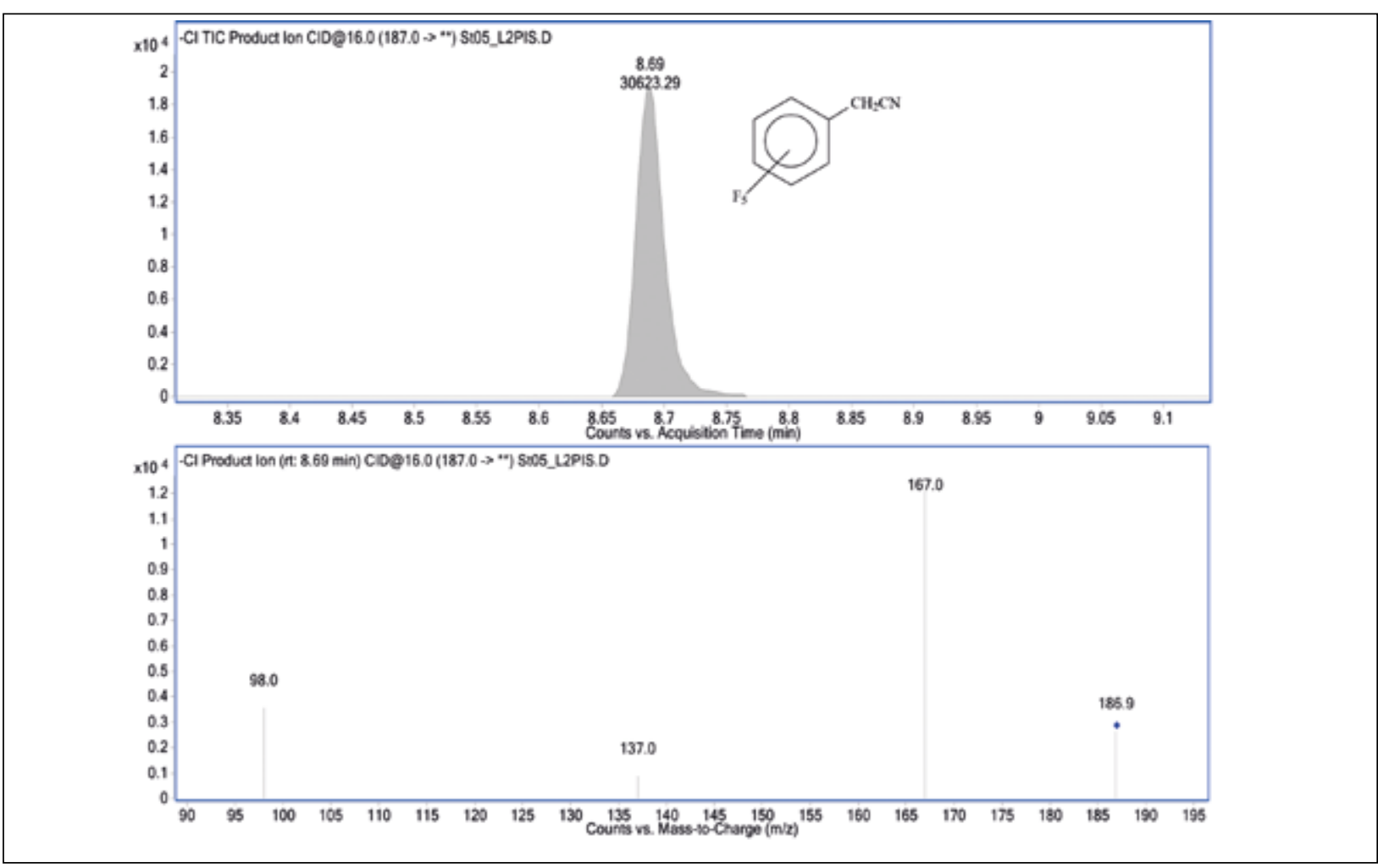

Рисунок 7 - Фрагмент хроматограммы по полному ионному току и MS/MS - спектр отрицательной химической ионизации 2,3,4,5,6-пентафторбензилацетонитрила, зарегистрированные nри MS/MS - сканировании в режиме «Product lon Scan» (m/z 187) (концентрация аналита - 1,0 мкг/мл в абс. этилацетате)

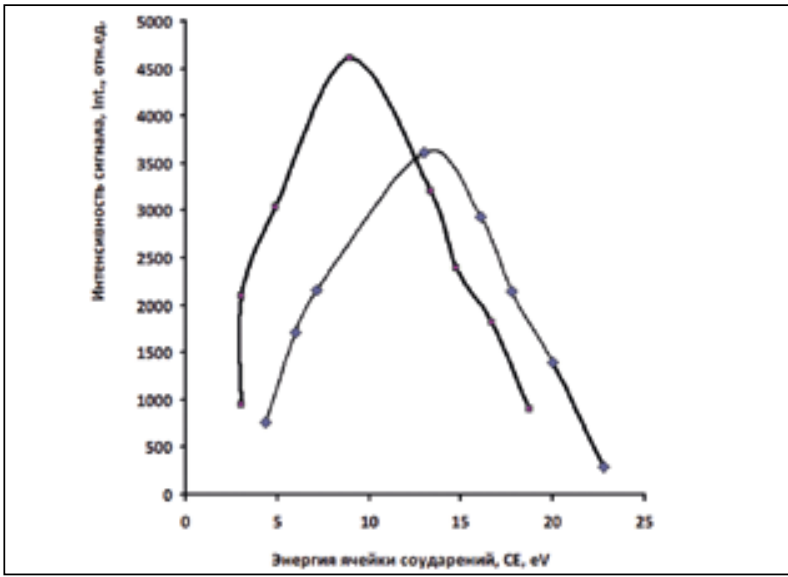

Рисунок 8 - Определение оптимальной энергии ячейки соударений при электронной ионизации определяемого аналита в режиме MS/MS-сканирования "MRM»

(с концентрацией 20,0 нг/мл в абс. этилацетате) для масс-энергетических переходов: $A$ - для $\mathrm{m} / \mathrm{z}$ (207 $\rightarrow$ 157), Б - для $\mathrm{m} / \mathrm{z}(207 \rightarrow 188)$

режимах химической ионизации наблюдается в интервале значений энергии ячейки соуда-

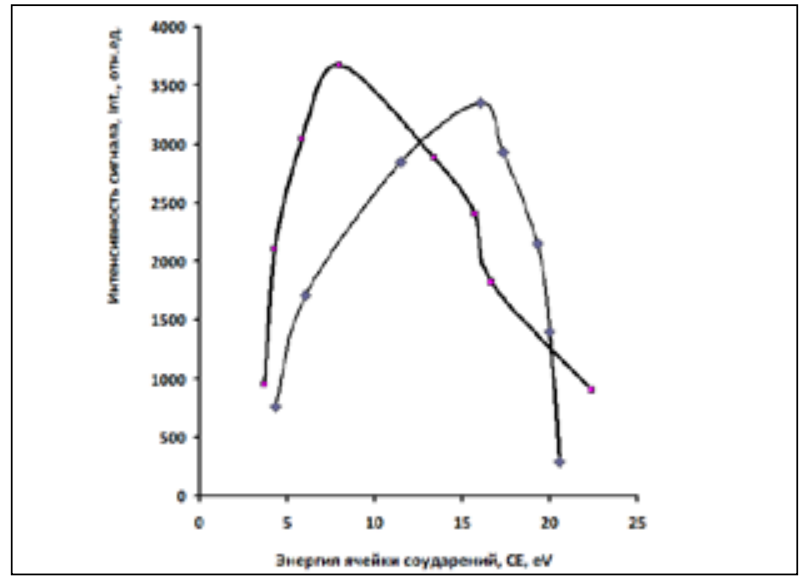

Рисунок 9 - Определение оптимальной энергии ячейки соударений при отрицательной химической ионизации определяемого аналита в режкиме MS/MS-сканирования "MRM»

(с концентрацией 35,0 нг/мл в абс. этилацетате) для масс-энергетических переходов: $A$ - для $\mathrm{m} / \mathrm{z}$ $(187 \rightarrow 167), 5$ - для $\mathrm{m} / \mathrm{z}(187 \rightarrow 98)$

рений от 2,0 до 20,0 эВ и коэффициентов усиления сигнала (Gain) от 2 до $10^{16}$.

16 Руководство пользователя работы с газовым хроматографом «Agilent 7890A» и масс-селективным детектором «Agilent 7000B GC/MS Triple Quad»: «Agilent Technologies, Inc.», СШA, 2013. Mass Hunter 


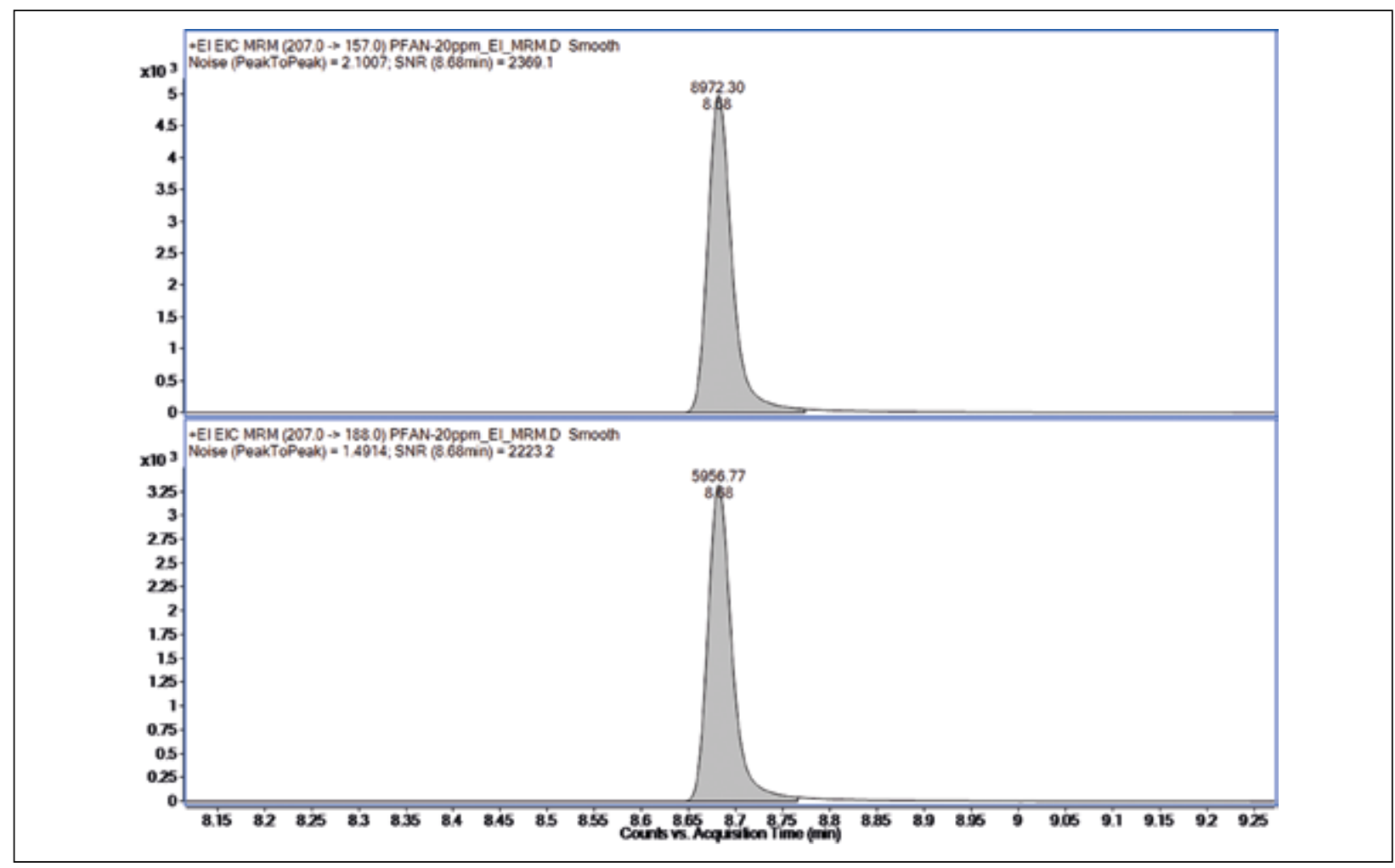

Рисунок 10 - Фрагменты хроматограмм электронной ионизации

2,3,4,5,6-пентафторбензилацетонитрила по выделенным масс-энергетическим переходам $\mathrm{m} / \mathrm{z}$ $(207 \rightarrow 157)$ nри 13 эВ и m/z (207 $\rightarrow$ 188) nри CE=9 эВ, зарегистрированных при MS/MS-сканировании в режсиме «МRM» (концентрация аналита - 20,0 нг/мл в абс. этилацетате)

Определение оптимальной энергии ячейки соударений CE в режиме MS/MS-сканирования «MRM» в нашем случае проводили в условиях эксперимента с шагом с разницей в $2-5$ эВ и последующей регистрацией интенсивности сигналов основных ионов в MS/MS-спектрах по двум выделенным масс-энергетическим переходам. Концентрация вводимых образцов аналита составляла 20-50 нг/мл (рисунки 8 и 9).

В результате проведенных экспериментов было установлено, что оптимальной величиной коэффициента усиления сигнала (Gain) в выбранных условиях является значение, равное 5 , при этом диапазон измерения концентраций целевого аналита составил 1-100 нг/мл. Хроматограммы по выделенным масс-энергетическим переходам 2,3,4,5,6-пентафторбензилацетонитрила при разных типах ионизации в режиме MS/MS-сканирования «MRM» приведены на рисунках 10 и 11.

В целях окончательного выбора способа ионизации провели анализ ряда стандартных растворов с одинаковыми концентрациями растворов аналита в диапазоне 1,0 нг/мл 10,0 мкг/мл (по десяти точкам).
Графические зависимости площади хроматографического сигнала от концентрации 2,3,4,5,6-пентафторбензилацетонитрила при электронной и химической (отрицательной) ионизации приведены на рисунках 12 и 13.

Полученные расчетные значения среднеквадратичного отклонения от наложенной линии тренда линейной зависимости площади хроматографического сигнала от концентрации аналита в обоих случаях свидетельствуют о высокой валидности разработанной математической модели и уравнения для расчетов $\left(\mathrm{R}^{2}>0,99\right)$.

Математическая обработка зависимостей, представленных на рисунках 12 и 13, показала, что предел обнаружения 2,3,4,5,6-пентафторбензилацетонитрила находится в интервале 0,35$0,42 \mathrm{нг/мл.} \mathrm{Это} \mathrm{достигается} \mathrm{при} \mathrm{использовании}$ отрицательной химической ионизации метаном при MS/MS-сканировании в режиме «MRM». Условия регистрации данных представлены в таблице 3.

Вместе с тем, было установлено, что при проведении пробоподготовки различных образцов почв, загрязненных цианидами в концентрациях от 0,20 до 10,0 мг/кг, степень извлечения

Workstation Software, Qualitative and Quantitative Analysis, version B.08.00 build 4.0.548.0: Agilent Technologies, Inc., США. 2016 


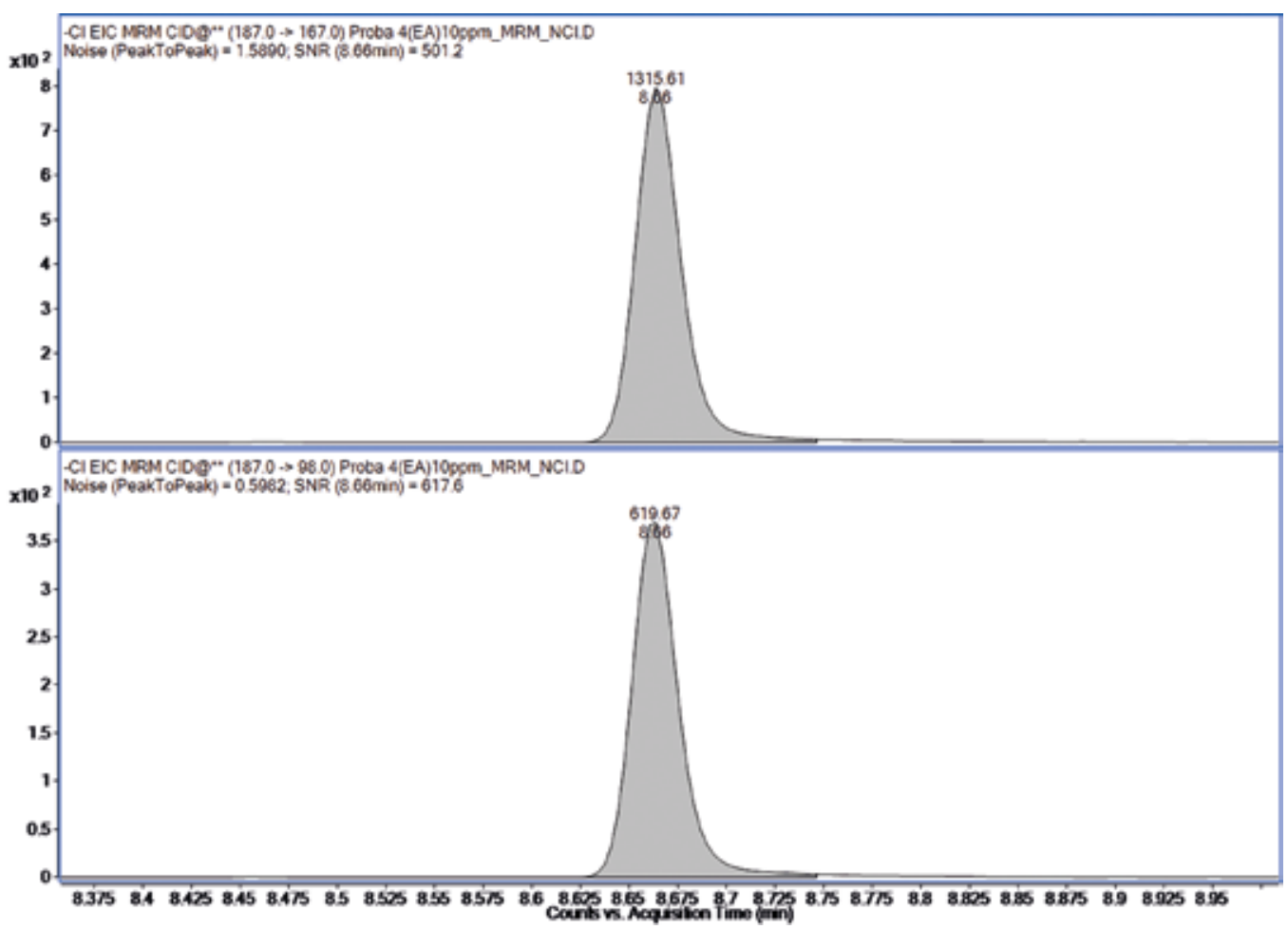

Рисунок 11 - Фрагменты хроматограмм отрицательной химической ионизации

2,3,4,5,6-пентафторбензилацетонитрила по выделенным масс-энергетическим переходам $\mathrm{m} / \mathrm{z}$ $(187 \rightarrow 167)$ nри 8 эВ и m/z $(187 \rightarrow 98)$ nри CE=16 эВ, зарегистрированных при MS/MS-сканировании $ө$ режкиме «MRM» (концентрация аналита - 25,0 нг/мл в абс. этилацетате)

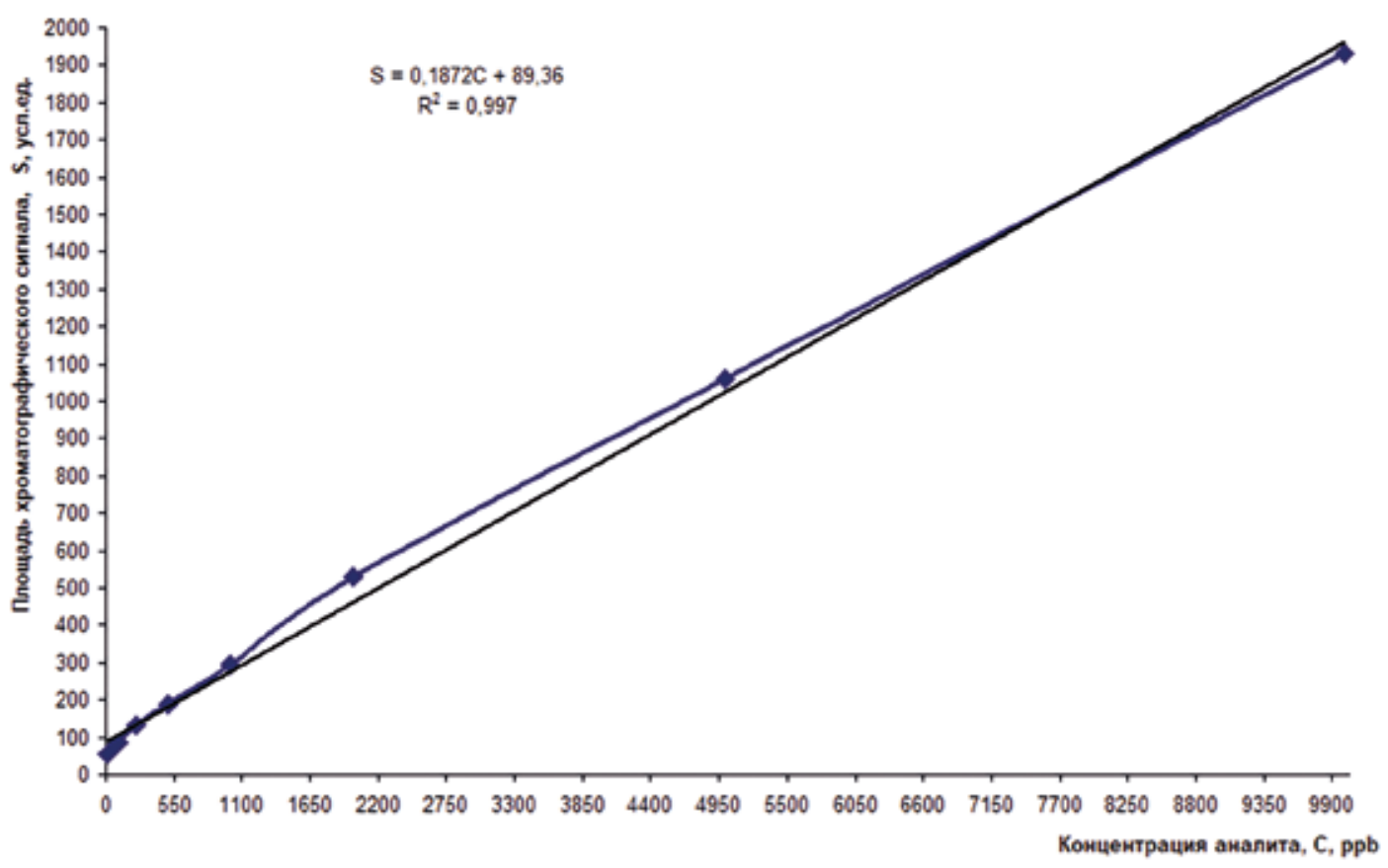

Рисунок 12 - Графическая зависимость площади хроматографического сигнала от концентрации раствора стандарта 2,3,4,5,6-пентафторбензилацетонитрила в этилацетате (электронная ионизация при MS/MS-сканировании в режиме «MRM») 


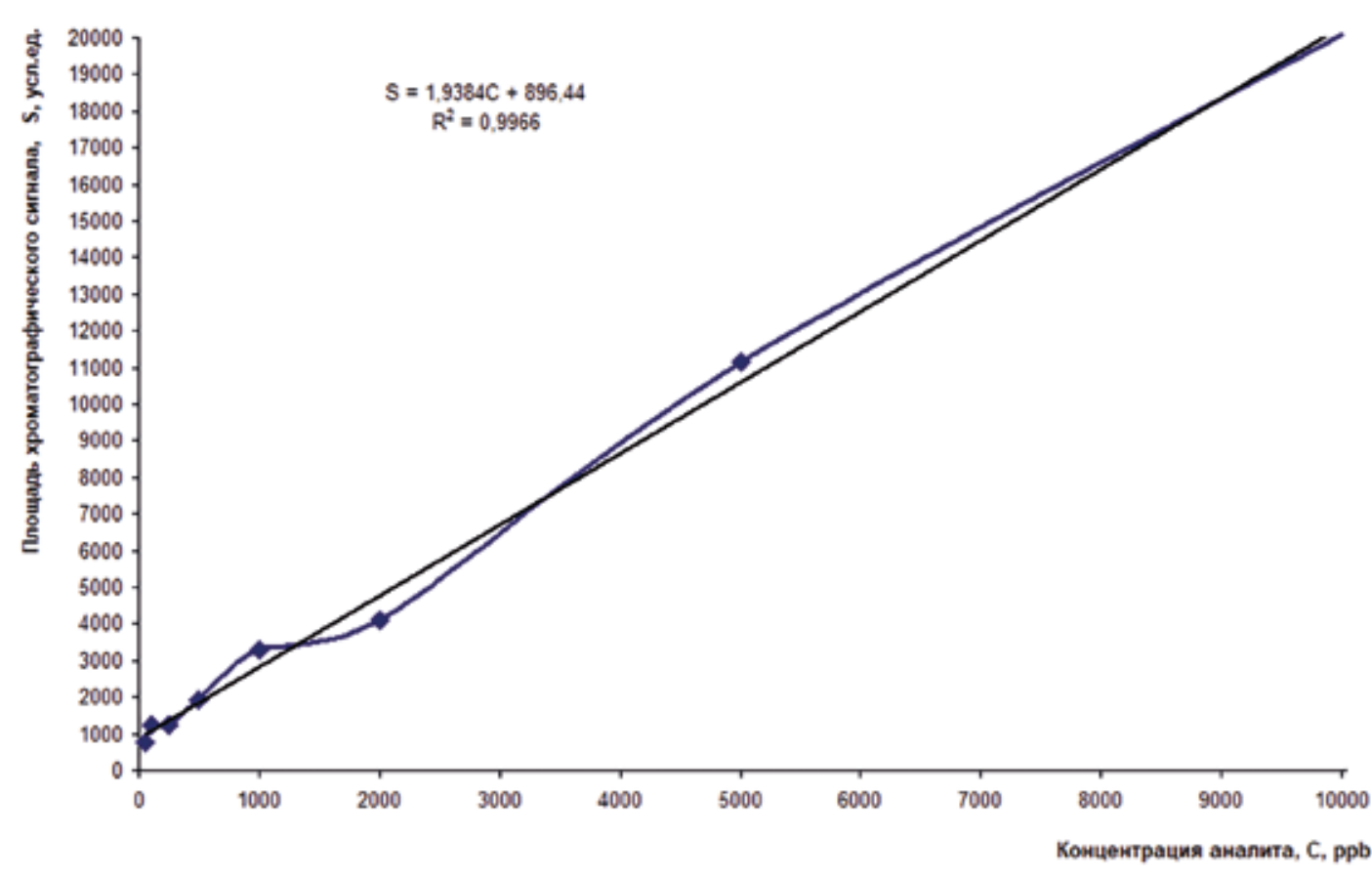

Рисунок 13 - Графическая зависимость площади хроматографического сигнала от концентрации раствора стандарта 2,3,4,5,6-пентафторбензилацетонитрила в этилацетате (отрицательная химическая ионизация метаном при MS/MS-сканировании в режиме «MRM»)

Таблица 3 - Условия анализа при обнаружении пентафторбензилацетонитрила методом газовой хроматографии с тандемным масс-спектрометрическим детектированием с использованием отрицательной химической ионизации метаном

\begin{tabular}{|c|c|c|c|c|}
\hline $\begin{array}{c}\text { Время удерживания } \\
\text { хроматографического } \\
\text { сигнала аналита, RT, } \\
\text { мин }\end{array}$ & $\begin{array}{c}\text { Основные масс- } \\
\text { энергетические } \\
\text { переходы } \\
\text { родительского } \\
\text { иона в продукт- } \\
\text { ион, } \mathrm{m} / \mathrm{z}\end{array}$ & $\begin{array}{c}\text { Энергия } \\
\text { ячейки } \\
\text { соударений, } \\
\text { СЕ, эВ }\end{array}$ & $\begin{array}{c}\text { Соотношение } \\
\text { интенсивностей } \\
\text { сигналов, \% }\end{array}$ & $\begin{array}{c}\text { Соотношение } \\
\text { сигнал : шум, SNR, } \\
\text { усл. ед., не менее }\end{array}$ \\
\hline \multirow{2}{*}{$8,68 \pm 0,1$} & $\begin{array}{c}187 \rightarrow 167 \\
\text { (качественный } \\
\text { анализ) } \\
\end{array}$ & 8,0 & 100 & \multirow{2}{*}{$5: 1$} \\
\hline & $\begin{array}{c}187 \rightarrow 98 \\
\text { (количественный } \\
\text { анализ) }\end{array}$ & 16,0 & $78 \pm 3$ & \\
\hline
\end{tabular}

цианид-ионов (по массе) составляет 68-77 \% (в среднем - 72,5 \%). При пересчете, с учетом среднего коэффициента извлечения, значение предела обнаружения цианида с помощью разработанного способа составило $(0,70 \pm 0,06) \times 10^{-3}$ мкг/г почвы, что существенно превышает ранее достигнутые и описанные в литературе результаты.

\section{Заключение}

На основании проведенного выше исследования, можно заключить, что надежную идентификацию и количественное определение цианид-ионов в почве в диапазоне 0,7 нг/г-10,0 мкг/г почвы, с учетом коэффициента извлечения, возможно проводить с помощью дериватизации цианидов 2,3,4,5,6-пентафторбензилбромидом и анализа методом газовой хроматографии с применением тандемного масс-селективного детектирования в режиме отрицательной химической ионизации метаном и мониторинга множественных реакций по основным массэнергетическим переходам, а также по времени удерживания в условиях разработанного метода.

Предложенный способ более чем на три десятичных порядка превосходит по чувствительности включенный в федеральный реестр 
фотометрический метод проведения количественного анализа проб почв на содержание цианидов и, кроме того, отличается меньшим временем проведения анализа, использованием меньшего количества химических реактивов и растворителей, что значительно уменьшает финансово-экономические затраты проведения процедуры в целом.
Полученные выше результаты могут быть реализованы при разработке и последующей государственной аттестации методики выполнения измерений содержаний цианид-ионов в почве методом газовой хроматографии с применением тандемного масс-селективного детектирования при химической ионизации метаном с регистрацией отрицательных ионов.

\section{Информация о конфликте интересов}

Авторы заявляют, что исследования проводились при отсутствии любых коммерческих или финансовых отношений, которые могли бы быть истолкованы как потенциальный конфликт интересов.

\section{Сведения о рецензировании}

Статья прошла открытое рецензирование двумя рецензентами, специалистами в данной области. Рецензии находятся в редакции журнала.

\section{Список источников}

1. Johnson C.A. The fate of cyanide in leach wastes at gold mines: An environmental perspective // Appl. Geochem. 2015. V. 57. P. 194-205.

2. Shifrin N.S., Beck B.D., Gauthier T.D. et al. Chemistry, toxicology, and human health risk of cyanide compounds in soils at former manufactured gas plant sites // Regul. Toxicol. Pharmacol. 1996. V. 23. P. 106-116.

3. Hilson G., Monhemius A.J. Alternatives to cyanide in the gold mining industry: What prospects for the future? // J. Clean. Prod. 2006. V. 14. P. 1158-1167.

4. Куценко С.А., Бутомо Н.В., Гребенюк А.Н. и др. Военная токсикология, радиобиология и медицинская защита: учебник / Под. ред. Куценко С.А. Спб. 2004.

5. Shifrin N.S., Beck B.D., Gauthier T.D. et al.
Chemistry, toxicology, and human health risk of cyanide compounds in soils at former manufactured gas plant sites // Regul. Toxicol. Pharmacol. 1996. V. 23. P. 106-116.

6. Campanella B., Biancalana L., D'Ulivo L. et al. Determination of total cyanide in soil by isotope dilution GC/MS following pentafluorobenzyl derivatization // Analyt. Chimica Acta. 2017. V. 961. P.74-81. http:// dx.doi.org/10.1016/j.aca.2017.01.026

7. Tsikas D. Pentafluorobenzyl bromide - versatile derivatization agent in chromatography and mass spectrometry. I. Analysis of inorganic anions and organophosphates // J. Chromatogr. B. 2017. V. 1043. P. 187-201. http://dx.doi.orgj10.1016/j.jchromb.2016.08.015

8. Лебедев А.Т. Масс-спектрометрия в органической химии. Изд. второе, перераб. и доп. М. 2015.

\section{Об авторах}

Федеральное государственное бюджетное учреждение «27 Научный центр» Министерства обороны Российской Федерации, 105005, г. Москва, Бригадирский переулок, д. 13.

Корнеев Дмитрий Олегович. Старший научный сотрудник научно-исследовательского отдела, канд. хим. наук, доц.

Понсов Михаил Александрович. Старший научный сотрудник научно-исследовательского отдела, канд. хим. наук, доц.

Родионов Александр Анатольевич. Старший научный сотрудник научно-исследовательского отдела, канд. техн. наук, проф. АВН.

Петракова Лидия Васильевна. Научный сотрудник научно-исследовательского отдела.

Рьбальченко Игорь Владимирович. Ведущий научный сотрудник научно-исследовательского отдела, доктор хим. наук, проф.

Контактная информация для всехавторов: 27nc_1@mil.ru Контактное лицо: Корнеев Дмитрий Олегович, 27nc_1@mil.ru 


\title{
Development of a method for measuring mass concentration of cyanides in soil samples using gas chromatography and tandem mass-selective detection
}

\author{
D.O. Korneev, M.A. Ponsov, A.A. Rodionov, L.V. Petrakova, I.V. Rybalchenko \\ Federal State Budgetary Establishment «27 Scientific Centre» of the Ministry \\ of Defence of the Russian Federation, Brigadirskii Lane 13, \\ Moscow 105005, Russian Federation
}

\begin{abstract}
The Convention on the Prohibition of the Development, Production, Stockpiling and Use of Chemical Weapons and on Their Destruction places $\mathrm{CN}$-containing toxic chemicals like tabun and its numerous homologues and analogues (around 10.000 organic compounds), hydrogen cyanide, cyanogen chloride etc., under the international control in the field of arms control, disarmament and non-proliferation. Moreover, $\mathrm{CN}$-containing toxic chemicals are hazardous industrial and environmental pollutants. Soils are the most widely-spread and complex environmental objects for the detection and analysis of cyanides. The aim of this work is to elaborate the method for measuring mass concentration of cyanides in soil samples, which is more sensitive and less labor-intensive, than photometric method, adopted in the Russian Federation. The developed method involves the use of 2,3,4,5,6-pentafluorobenzyl bromide as a derivatizing agent and GC/MS/MS with methane negative ion chemical ionization. It enables the identification and quantification of cyanide ions in soil in the range of $0.7 \mathrm{ng} / \mathrm{g}-10.0 \mu \mathrm{g} / \mathrm{g}$. This method is much more sensitive than the photometric method, included in the federal registry. It does not require the use of potassium cyanide isotopes with radioactive labels of carbon and potassium as an internal standard, and it requires less implementation time.
\end{abstract}

Keywords: 2,3,4,5,6-pentafluorobenzyl bromide; gas chromatography; derivatization; identification; quantification analysis; soil sample; chromato-mass-spectrometry; cyanide.

For citation: Korneev D.O., Ponsov M.A., Rodionov A.A., Petrakova L.V., Rybalchenko I.V. Development of a method for measuring mass concentration of cyanides in soil samples using gas chromatography and tandem mass-selective detection // Journal of NBC Protection Corps. 2019. V. 4. № 1. P. 4-20. https://doi. org/10.35825/2587-5728-2020-4-1-4-20

\section{Conflict of interest statement}

The authors declare that the research was conducted in the absence of any commercial or financial relationship that could be construed as a potential conflict of interest.

Peer review information

The article has been peer reviewed by two experts in the respective field. Peer reviews are available from the Editorial Board.

\section{References}

1. Johnson C.A. The fate of cyanide in leach wastes at gold mines: An environmental perspective // Appl. Geochem. 2015. V. 57. P. 194-205.

2. Shifrin N.S., Beck B.D., Gauthier T.D. et al. Chemistry, toxicology, and human health risk of cyanide compounds in soils at former manufactured gas plant sites // Regul. Toxicol. Pharmacol. 1996. V. 23. P. 106-116.

3. Hilson G., Monhemius A.J. Alternatives to cyanide in the gold mining industry: What prospects for the future? // J. Clean. Prod. 2006. V. 14. P. 1158-1167.
4. Kutsenko S.A., Butomo N.V., Grebenyuk A.N. et al. Military Toxicology, Radiobiology and Medical Protection: Textbook for Medical Students / Ed. Kutsenko S.A. St. Petersburg: Foliant, 2004 (in Russian).

5. Shifrin N.S., Beck B.D., Gauthier T.D. et al. Chemistry, toxicology, and human health risk of cyanide compounds in soils at former manufactured gas plant sites // Regul. Toxicol. Pharmacol. 1996. V. 23. P. 106-116.

6. Campanella B.., Biancalana L., D'Ulivo L. et al. 
Determination of total cyanide in soil by isotope dilution GC/MS following pentafluorobenzyl derivatization // Analytica Chimica Acta. 2017. V. 961. P. 74-81. http:// dx.doi.org/10.1016/j.aca.2017.01.026

7. Tsikas D. Pentafluorobenzyl bromide versatile derivatization agent in chromatography and mass spectrometry. I. Analysis of inorganic anions and organophosphates // J. Chromatogr. B. 2017. V. 1043. P. 187-201. http://dx.doi.orgj10.1016/j. jchromb.2016.08.015

8. Lebedev A.T. Mass Spectrometry in Organic Chemistry. 2nd edition. Moscow, 2015.

\section{Authors}

Federal State Budgetary Establishment «27 Scientific Centre» of the Ministry of Defence of the Russian Federation. Brigadirskii Lane 13, Moscow 105005, Russian Federation.

Dmitry Olegovich Korneev. Senior Researcher of the Department. Candidate of Chemical Sciences, Associate Professor.

Mikhail Aleksandrovich Ponsov. Senior Researcher of the Department. Candidate of Chemical Sciences, Associate Professor.

Aleksandr Anatolyevich Rodionov. Senior Researcher of the Department. Candidate of Technical Sciences, Professor of the Academy of Military Sciences.

Lidia Vasilyevna Petrakova. Researcher of the Department.

Igor Vladimirovich Rybalchenko. Leading Researcher of the Department. Doctor of Chemical Sciences, Professor.

Contact information for all authors: 27nc_1@mil.ru Contact person: Korneev Dmitry Olegovich; 27nc_1@mil.ru 